Novriansyah, et al/Jurnal Ekonomi Syariah Teori dan Terapan Vol. 6 No. 8 Agustus 2019: 1718-1732; PERAN PEMBIAYAAN PRODUK ARRUM BPKB PT PEGADAIAN SYARIAH DALAM MENGEMBANGKAN USAHA MIKRO KECIL DAN MENENGAH DI KOTA SURABAYA

\title{
PERAN PEMBIAYAAN PRODUK ARRUM BPKB PT PEGADAIAN SYARIAH DALAM MENGEMBANGKAN USAHA MIKRO KECIL DAN MENENGAH DI KOTA SURABAYA ${ }^{1}$
}

\author{
Muh Novriansyah \\ Departemen Ekonomi Syariah - Fakultas Ekonomi dan Bisnis - Universitas Airlangga \\ Email: muhnovriansyah1@gmail.com \\ Sri Herianingrum \\ Departemen Ekonomi Syariah - Fakultas Ekonomi dan Bisnis - Universitas Airlangga \\ Email: sriheria@yahoo.co.id
}

\begin{abstract}
:
In 2017, Bank Indonesia (BI) stated that the contribution of MSMEs was very large in encouraging economic growth with values reaching Rp. 850 trillion per year. This study aims to analyze the role of financing for ARRUM BPKB products managed by PT. Pegadaian Syariah plays a role in developing MSMEs in the city of Surabaya. This study aims to analyze the role of financing for ARRUM BPKB products managed by PT. Pegadaian Syariah plays a role in developing MSMEs in the city of Surabaya. The results of this study indicate that the financing of ARRUM BPKB products managed by PT. Pegadaian Syariah plays a role in facility standards in the form of increasing assets and facilities and infrastructure, then in the guidance standard there isa form of increasing knowledge about tips in entrepreneurship, management skills, accounting skills and marketing abilities, and roles in financing standards in the form of increased business turnover resulting in the development of business owned by customers of PT. Sharia Pawnshop.
\end{abstract}

Keywords: Sharia pawnshops, ARRUM BPKB products, MSMEs.

\section{PENDAHULUAN}

Perekonomian suatu negara adalah suatu hal yang penting, khususnya dalam pertumbuhan ekonomi atau pertumbuhan Produk Domestik Bruto (PDB) seringkali menjadi bahasan yang penting dalam pemerintahan disuatu negara.Berdasarkan data dari Badan Pusat Statistik (BPS) terbaru pada tahun 2017 persentase tingkat pertumbuhan Produk Regional Domestik Bruto (PRDB) di kota Surabaya cenderung mengalami peningkatan. Pada periode 2016nilai PRDB kota surabaya mencapai Rp. 451 triliyun, sedangkan periode tahun 2017 PRDB di kota Surabaya mencapai Rp. 495 triliyun (BPS, 2017).

Pada tahun 2017, Bank Indonesia (BI) menyatakan kontribusi UMKM sangat besar mendorong pertumbuhan ekonomi dengan nilai mencapai Rp. 850 triliun per tahun pada Produk Domestik Bruto (PDB) sementara Badan Pusat Statistik (BPS) menyatakan kontribusi UMKM terhadap perekonomian nasional mencapai 61,41 persen dengan penyerapan tenaga kerja mendominasi sekitar 97 persen dari total tenaga kerja nasional yang tersedia (Masyrafina, 2017).Dalam pelaksanaan pembangunan ekonomi khususnya di kota Surabaya masih banyak ditemukan

\footnotetext{
${ }^{1}$ Jurnal ini merupakan bagian dari skripsi Muh Novriansyah, NIM: 041511433082, yang diuji pada tanggal 25 Juni 2019.
} 
Novriansyah, et al/Jurnal Ekonomi Syariah Teori dan Terapan Vol. 6 No. 8 Agustus 2019: 1718-1732;

PERAN PEMBIAYAAN PRODUK ARRUM BPKB PT PEGADAIAN SYARIAH DALAM MENGEMBANGKAN USAHA MIKRO KECIL DAN MENENGAH DI KOTA SURABAYA

berbagai macam masalah yang menghambat pertumbuhan UMKM. Menurut Kara (2013) salah satu persoalan utama dalam pengembangan usaha khususnya UMKM adalah keterbatasan dalam permodalan yang disebabkan antara lain; ketersediaan jaminan yang dimiliki UMKM tidak mencukupi persyaratan pengajuan pembiayaan, sebagian besar UMKM tidak memiliki legalitas formal usaha dan tata administrasi yang tidak teratur utamanya terkait pengelolaan keuangan, dan rumitnya berkas pengajuan permohonan pembiayaan yang membuat pemilik usaha enggan sementara dirinya juga harus mengelola usahanya.

Salah satu solusi dari persoalan tersebut adalah dengan menyediakan pembiayaan bagi usaha mikro melalui berbagai instrumen pembiayaan mikro bebas bunga, salah satunya adalah melalui BMT. Pembiayaan BMT selalu menggunakan berbagai akad syariah dalam memenuhi fungsinya sebagai lembaga intermediasi keuangan mikro, serta lebih banyak menggunakan akadakad yang bergerak langsung di sektor riil (Prasetya dan Herianingrum, 2016).Berdasarkan hasil temuan Herianingrum (2013:178) apabila pembiayaan mengalami peningkatan maka kinerja usaha dan kesejahteraan pengusaha kecil juga akan mengalami peningkatan pula, pembiayaan pada lembaga keuangan syariah yang menggunakan sistem bagi hasilnya sangat diharapkan oleh para pengusaha, khususnya pengusaha kecil karena dengan sistem bagi hasil diharapkan tidak akan tidak akan mendzolimi pengusaha apabila mereka mengalami kerugian karena telah ada kesepakatan apabila pengusaha rugi, dalam hal ini berbeda dengan sistem bunga, dimana pengusaha harus tetap membayar bunga walaupun usahanya rugi. Tetapi pembiayaan bagi usaha mikro dengan menggunakan prinsip syariah tidak hanya dilakukan melalui BMT, namun juga dapat dilakukan melalui lembaga keuangan syariah yang lainnya salah satunya adalah PT. Pegadaian Syariah.

$$
\text { Hadirnya Pegadaian Syariah }
$$
sebagai sebuah lembaga keuangan formal yang berbentuk unit dari PT Pegadaian di Indonesia, yang bertugas menyalurkan pembiayaan dalam bentuk pemberian vang pinjaman kepada masyarakat yang membutuhkan berdasarkan hukum gadai syariah merupakan suatu hal yang perlu mendapatkan sambutan positif. Dalam gadai syariah yang terpenting adalah dapat memberikan kemaslahatan sesuai dengan yang diharapkan masyarakat dan menjauhkan diri praktik-praktik riba', gimar (spekulasi), maupun gharar (ketidaktransfaran) yang berakibat terjandinya ketidakadilan dan kedzaliman pada masyarakat dan nasabah (Diana, 2016).Konsep dan fungsi operasi pegadaian Islam 
Novriansyah, et al/Jurnal Ekonomi Syariah Teori dan Terapan Vol. 6 No. 8 Agustus 2019: 1718-1732; PERAN PEMBIAYAAN PRODUK ARRUM BPKB PT PEGADAIAN SYARIAH DALAM MENGEMBANGKAN USAHA MIKRO KECIL DAN MENENGAH DI KOTA SURABAYA

mengacu pada sistem administrasi modern yaitu asas rasionalitas, efisiensi, dan efektivitas yang diselaraskan dengan nilai Islam (Huda dan Heykal, 2010). Ade Sofyan Mulazid (2016) berpendapat bahwa rahn adalah perjanjian penyerahan barang sebagai jaminan sehingga orang yang bersangkutan boleh mengambil utang. Dengan demikian, tampak bahwa fungsi dari barang jaminan adalah untuk memberikan keyakinan, ketenangan, dan keamanan atas utang yang dipinjamkan.

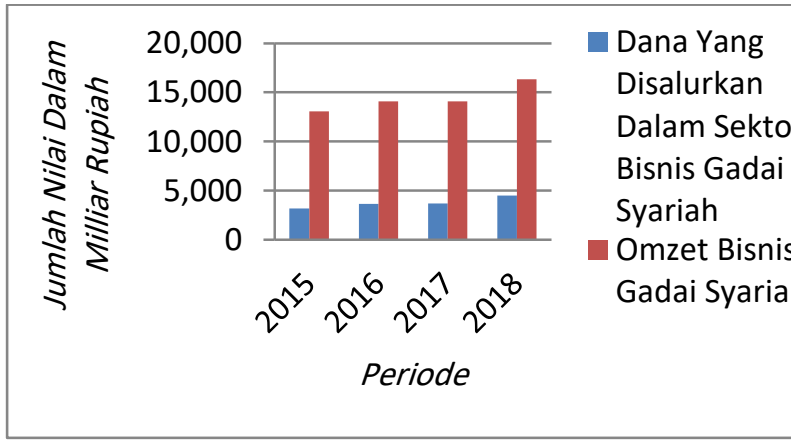

Sumber: Laporan Tahunan PT Pegadaian Periode 2015-2018, Diolah Peneliti

Gambar 1.

Laju Pertumbuhan Sektor Bisnis Gadai Syariah Periode2015-2018

Berdasarkan laporan tahunan PT Pegadaian Syariah pada gambar 1.1 dapat diketahui bahwa dana yang disalurkan dan omzet pada sektor bisnis gadai syariah periode tahun 2015 sebanyak Rp. 3.199 miliar dan Rp. 13.078 miliar. Selanjutnya pada periode tahun 2016 mengalami pertumbuhan sebesar 14,59\% atau Rp. Rp. 3.666 miliar untuk dana yang disalurkan dan pertumbuhan sebesar 7,79\% atau Rp. 14.097 miliar untuk omzet bisnis sektor Gadai Syariah. Disusul pada periode tahun 2017 juga mengalami pertumbuhan dari tahun sebelumnya sebesar $1,30 \%$ atau Rp. 3.723 miliar untuk dana yang disalurkan dan pertumbuhan sebesar $6,05 \%$ atau Rp. 14.950 miliar untuk omzet sektor bisnis Gadai Syariah. Kemudian data terbaru menyatakan pada periode tahun 2018 mengalami pertumbuhan yang sangat pesat sebesar 20,6\% atau Rp. 4.489 milliar untuk dana yang disalurkan dan pertumbuhan sebesar 9,2\% atau Rp. 16.319 milliar untuk omzet sektor bisnis Gadai Syariah. Guna mendukung pertumbuhan ekonomi nasional dalam PT Pegadaian Syariah juga mempunyai produk lain yang berfokus pembiayaan atau akses permodalan di sektor UMKM, salah satu produk tersebut adalah Pembiayaan Ar Rahn Untuk Usaha Mikro (ARRUM BPKB) (www.pegadaian.co.id).

Produk pembiayaan ARRUM BPKB adalah skim pinjaman yang berbasis syariah guna memudahkan para pengusaha kecil untuk mendapatkan modal usaha yang digunakan untuk pengembangan usaha dengan sistem pengembalian secara angsuran yang berjangka waktu fleksibel, dengan menggunakan jaminan BPKB kendaraan bermotor

(www.pegadaiansyariah.co.id). Dengan adanya produk ARRUM BPKB ini sangat memudahkan masyarakat untuk memperoleh modal usaha, disisi lain kendaraan tetap pada pemiliknya sehingga dapat digunakan untuk mendukung aktivitas usaha UMKM yang 
Novriansyah, et al/Jurnal Ekonomi Syariah Teori dan Terapan Vol. 6 No. 8 Agustus 2019: 1718-1732; PERAN PEMBIAYAAN PRODUK ARRUM BPKB PT PEGADAIAN SYARIAH DALAM MENGEMBANGKAN USAHA MIKRO KECIL DAN MENENGAH DI KOTA SURABAYA

dapat memaksimalkan daya guna kendaraan tersebut.Landasan hukum peluncuran skim pembiayaan dengan sistem syariah pada produk ARRUM BPKB untuk pengembangan Usaha Mikro Kecil dan Menengah (UMKM) didasari oleh Fatwa No. 25/DSN-MUI/III/2002 tentang Rahn, Fatwa No. 68/DSN-MUI/III/2008 tentang Rahn Tasjily, Fatwa No. 92/DSNMUI/IV/2014 tentang Pembiayaan Yang Disertai Rahn.

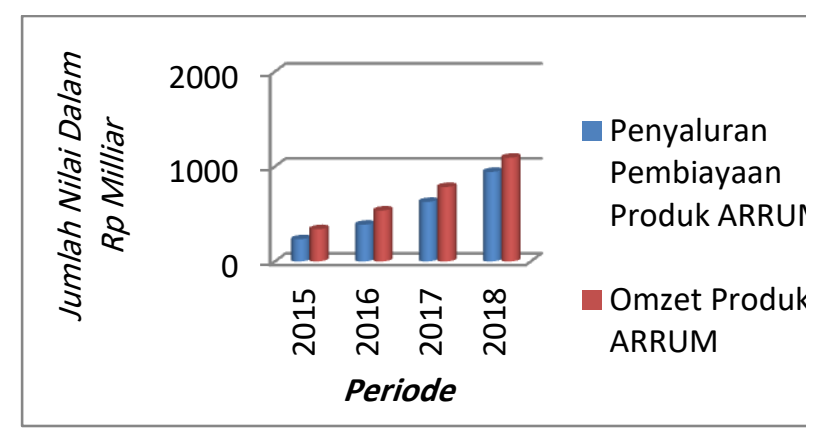

Sumber: Laporan Tahunan PT Pegadaian Periode 2015-2018, Diolah Peneliti

Gambar 2.

Laju Pertumbuhan Produk Pembiayaan ARRUM Periode2015-2018

Berdasarkan laporan tahunan PT.

Pegadaian dapat diketahui pada gambar 1.2 bahwa pada produk ARRUM pembiayaan yang disalurkan dan omzet bisnis periode 2015 mencapai Rp. 233,494 milliar dan Rp. 339,403 milliar. Selanjutnya pada periode tahun 2016 mengalami pertumbuhan sebesar 65,49 persen atau Rp. 386,416 milliar untuk pembiayaan yang disalurkan dan pertumbuhan sebesar 57,96 persen atau Rp. 536,107 milliar untuk omzet bisnis produk ARRUM. Disusul pada periode tahun 2017 juga mengalami pertumbuhan dari tahun sebelumnya sebesar 62,38 persen atau Rp. 627,460 milliar untuk pembiayaan yang disalurkan dan pertumbuhan sebesar 46,26 persen atau Rp. 784,131 milliar untuk omzet bisnis produk ARRUM. Kemudian data terbaru menyatakan pada periode tahun 2018 mengalami pertumbuhan yang sangat pesat sebesar 50,4\% atau Rp. 943,474 milliar untuk dana yang disalurkan dan pertumbuhan sebesar $39,3 \%$ atau Rp. $1.092,603$ milliar untuk omzet sektor bisnis produk ARRUM (www.pegadaian.co.id). Dengan melihat data yang telah dipaparkan tersebut, hal ini merupakan perkembangan yang luar biasa dalam sektor pembiayaan untuk UMKM oleh Pegadaian Syariah.

\section{TINJAUAN PUSTAKA}

Menurut Rivai dan Veithzal (2008:9) Istilah pembiayaan pada intinya berarti I Believe, I Trust, 'saya percaya atau 'saya menaruh kepercayaan'.Perkataan pembiayaan yang artinya kepercayaan (trust), berarti lembaga pembiayaan selaku shahibul mal menaruh kepercayaan kepada seseorang untuk melaksanakan amanah yang diberikan. Dana tersebut harus digunakan dengan benar, adil, dan harus disertai dengan ikatan dan syaratsyarat yang jelas, dan saling menguntungkan bagi kedua belah pihak. Pembiayaan syariah dapat ditinjau dari sisi tujuan dilakukannya pembiayaan tersebut, meliputi:

1. Pembiayaan konsumtif bertujuan untuk memperoleh barang-barang 
Novriansyah, et al/Jurnal Ekonomi Syariah Teori dan Terapan Vol. 6 No. 8 Agustus 2019: 1718-1732;

PERAN PEMBIAYAAN PRODUK ARRUM BPKB PT PEGADAIAN SYARIAH DALAM MENGEMBANGKAN USAHA MIKRO KECIL DAN MENENGAH DI KOTA SURABAYA

ataukebutuhan-kebutuhan lainnya guna memenuhi keputusan dalam konsumsi.

2. Pembiayaan produktif bertujuan untuk memungkingkan penerima pembiayaan dapat mencapai tujuannya yang apabila tanppa pembiayaantersebut tidak mungkin dapat diwujudkan. Pembiayaan produktif adalah bentuk pembiayaan yang bertujuan untuk memperlancar jalannya proses produksi, mulai dari saat pengumpulan bahan mentah, pengolahan, dan sampai kepada proses penjualan barang-barang yang sudah jadi.

Pegadaian Syariah memiliki tiga prinsip yang bersumberkan pada kajian ekonomi Islam. Prinsip pengembangan ekonomi tidak saja mengacu pada proses dimana masyarakat dari suatu Negara memanfaatkan sumber yang tersedia untuk menghasilkan kenaikan produksi barang dan jasa secara terusmenerus, akan tetapi Islam memiliki prinsip-prinsip pengembangan yang dibingkai dengan kerangka hubungan dengan Allah dan menyeimbangkan antara kehidupan di dunia dan di akhirat (Mannan, 1975). Menurut Mulazid (2016:23) prinsip-prinsip pembiayaan dalam konteks pengembangan ekonomi umat khususnya pembiayaan gadai syariah, sebagai berikut:

1. Prinsip tauhid (tawhid), gadai dengan prinsip tawhid dapat mengukuhkan konsep non materialistik dan dipahami sebagai triangle, dimana ketaatan kepada Tuhan diletakkan pada posisi puncak, sedangkan manusia dan alam diletakkan pada posisi sejajar yang saling membutuhkan. Ajaran Islam memandang kebiasaan untuk mendiamkan harta yang diperoleh tidak dianjurkan dalam Islam, karena akan menyebabkan harta tersebut hanya dimiliki oleh segelintir orang kaya dan Islam menghendaki terjadinya perputaran kepemilikan harta secara lebih merata.

2. Prinsip tolong-menolong (ta'wun), Menurut Abu Yusuf dalam Mulazid (2016:25) menyebutkan bahwa prinsip yang harus diletakkan dalam transaksi gadai adalah ta'awun (tolongmenolong), yaitu prinsip salingmembantu antar sesame dalam meningkatkan taraf hidup melalui mekanisme kerjasama ekonomi dan bisnis.

3. Prinsip bisnis (tijarah), Menurut Antonio dalam Mulazid (2016:26) dalam kacamata Islam tidak ada dikotomi antara usaha-usaha untuk pembangunan ekonomi maupun sektor-sektor lainnya dengan persiapan untuk kehidupan di akhirat nanti. Karena itu, kegiatan bisnis gadai syariah, tanpa mengikuti aturan-aturansyariah akan membawa kehancuran. Prinsip-prinsip usaha gadai syariah dapat dijadikan pedoman dalam usaha pegadaian 
Novriansyah, et al/Jurnal Ekonomi Syariah Teori dan Terapan Vol. 6 No. 8 Agustus 2019: 1718-1732;

PERAN PEMBIAYAAN PRODUK ARRUM BPKB PT PEGADAIAN SYARIAH DALAM MENGEMBANGKAN USAHA MIKRO KECIL DAN MENENGAH DI KOTA SURABAYA

syariah. Karena itu, prinsip-prinsip usaha pegadaian syariah, yakni:

a. Sikap saling ridha antar kedua belah pihak

b. Menegakkan prinsip keadilan dalam proporsi keuntungan

c. Tidak melakukan investasi pada usaha yang diharamkan

d. Bisnis terhindar dari gharar, tadlis, dan maysir

e. Pencatatan dalam kegiatan bisnis. Menurut Mulazid (2016), Transaksi hukum gadai dalam fikih Islam disebut alRahn, yang secara bahasa dapat disimpulkan dengan tetap, kekal, dan menahan suatu barang sebagai pengikat hutang. Definisi Al-Rahn adalah perjanjian penyerahan barang sebagai jaminan sehingga orang yang bersangkutan boleh mengambil hutang. Dengan demikian, tampak fungsi dari barang jaminan adalah untuk memberi keyakinan, ketenangan, dan keamanan atas utang yang dipinjamkan. Berdasarkan prinsip syariah, gadai yang dikenal dengan istilah Rahn dibedakan menjadi dua jenis, yaitu:

1. Rahn, berdasarkan fatwa DSN-MUI No. 25/DSN-MUI/III/2002tentang

Rahn, adalah pinjaman dengan menggadaikan barang sebagai jaminan utang.

2. Rahn Tasjily, berdasarkan fatwa DSNMUI No.68/DSN-MUI/III/2008 tentang Rahn Tasjily, adalah jaminan dalam bentuk barang atas utang, dengan kesepakatan bahwa yang diserahkan kepada penerima jaminan (murtahin) hanya bukti sah kepemilikannya, sedangkan fisik barang jaminan tersebut (marhun) tetap berada dalam penguasaan dan pemanfaatan pemberi jaminan (rahin).

Dasar hukum gadai syariah yang disebut dengan rahn sebagai kegiatan muamalah dapat merujuk pada firman Allah yang tertuang pada kitab suci AlQur'an, hadits Nabi Muhammad SAW, ijma ulama dan fatwa DSN-MUI. Berkaitaitan dengan hal tersebut, berikut merupakan landasan hukum rahn:

1. Kitab suci Al-Qur'an Surat Al-Baqarah ayat 283

2. Kitab suci Al-Qur'an Surat An-Nisaa' ayat 29

3. Hadis Nabi riwayat Al-Bukhari No. 2330

4. Dasar hukum yang selanjutnya untuk dijadikan acuan dalam membuat rumusan gadai syariah adalah ijma ulama. Jumhur ulama menyepakati kebolehan status hukum gadai. Hal dimaksud, didasarkan pada kisah Nabi Muhammad SAW yang menggadaikan baju besinya untuk mendapatkan makanan dari seorang Yahudi. Para ulama juga mengambil indikasi dari contoh tersebut, ketika beliau beralih dari yang biasanya bertransaksi kepada para sahabat yang kaya kepada seorang Yahudi, bahwa hal itu tidak lebih sebagai sikap Nabi yang tidak mau memberatkan sahabat. Mereka biasanya enggan mengambil ganti ataupun harga yang diberikan oleh Nabi (Zuhayli, 1985). 
Novriansyah, et al/Jurnal Ekonomi Syariah Teori dan Terapan Vol. 6 No. 8 Agustus 2019: 1718-1732; PERAN PEMBIAYAAN PRODUK ARRUM BPKB PT PEGADAIAN SYARIAH DALAM MENGEMBANGKAN USAHA MIKRO KECIL DAN MENENGAH DI KOTA SURABAYA

5. Dasar hukum yang selanjutnya untuk dijadikan acuan dalam bertransaksi menggunakan akad rahntertuang di beberapa Fatwa DSN-MUI, diantaranya:

a. Fatwa DSN-MUI No. 25/DSNMUI/III/2002 tentang Rahn.

b. Fatwa DSN-MUI No. 68/DSNMUI/III/2008 tentang Rahn Tasjily.

c. Fatwa DSN-MUI No. 26/DSNMUI/III/2002 tentang Rahn Emas.

Huda dan Heykal (2010:279) menyatakan bahwa rukun dari akad transaksi rahn tersebut, meliputi:

1. Orang yang berakad:

a. Yang berutang (rahin); dan

b. Yang berpiutang (murtahin).

2. ljab kabul (sighat).

3. Harta yang di-rahn-kan (marhun).

4. Pinjaman (marhun bih).

Menurut Huda dan Heykal (2010:280) adapunketentuan atau persyaratan yang menyertai akad rahn itu sendiri. Dengan demikian syarat-syarat rahn, meliputi:

1. Akad. Akad tidak mengandung syarat fasik/batil seperti murtahin mensyaratkan jaminan dapat dimanfaatkan tanpa batas.

2. Marhun Bih (pinjaman). Pinjaman merupakan hak yang wajib dikembalikan kepada murtahin dan bisa dilunasi dengan barang yang dirahn-kan tersebut. Serta, pinjaman itu jelas dan tertentu.

3. Marhun (barang yang digadaikan). Marhun bisa dijual dan nilainya seimbang dengan pinjaman, memiliki nilai, jelas ukurannya, milik sah penuh dari rahin, tidak terkait dengan hak orang lain, dan bisa diserahkan baik materi maupun manfaatnya.

4. Jumlah maksimum dana rahn dan nilai likuidasi barang yang di-rahn-kan serta jangka waktu rahn ditetapkan dalam prosedur.

5. Rahin dibebani jasa manajemen atas barang berupa; biaya asuransi, penyimpanan, keamanan, dan pengelolaan serta administrasi.

Pegadaian Syariah adalah lembaga keuangan formal yang merupakan unit dari PT. Pegadaian (Persero) di Indonesia, dengan tugas menyediakan alternatif pemenuhan kebutuhan pembiayaan bagi kelompok masyarakat menengah ke bawah yang memiliki usaha berskala mikro, kecil maupun menengah berdasarkan hukum rahn atau gadai syariah (Syafruddin, 2014; Mutmainnah, 2012).Pegadaian syariah dalam pengoprasiannya menggunakan metode Fee Base Income(FBI) atau Mudharabah (bagi hasil). Karena nasabah dalam mempergunakannya mempunyai tujuan yang berbeda-beda. Konsep operasi pegadaian Islam mengacu pada sistem administrasi modern yaitu asas rasionalitas, efisiensi, dan efektivitas yang diselaraskan dengan nilai Islam. Fungsi operasi Pegadaian Syariah mengacu pada sistem administrasi modern yaitu asas rasionalitas, efisiensi, dan efektivitas yang diselaraskan dengan nilai Islam. Fungsi operasi Pegadaian Syariah itu 
Novriansyah, et al/Jurnal Ekonomi Syariah Teori dan Terapan Vol. 6 No. 8 Agustus 2019: 1718-1732; PERAN PEMBIAYAAN PRODUK ARRUM BPKB PT PEGADAIAN SYARIAH DALAM MENGEMBANGKAN USAHA MIKRO KECIL DAN MENENGAH DI KOTA SURABAYA

sendiri dijalankan oleh kantor-kantor Cabang Pegadaian Syariah/Unit Layanan Gadai Islam (ULGS) sebagai satu unit organisasi dibawah binaan Divisi Usaha Lain Perum Pegadaian. ULGS ini merupakan unit bisnis mandiri yang secara struktural terpisah pengelolaannya dari usaha gadai konvensional (Huda dan Heykal, 2010).

Dalam pegadaian syariah yang terpenting adalah dapat memberikan kemaslahatan sesuai dengan yang diharapkan masyarakat dan menjauhkan diri praktik-praktik riba', qimar (spekulasi), maupun gharar (ketidaktransfaran) yang berakibat terjandinya ketidakadilan dan kedzaliman pada masyarakat dan nasabah (Diana, 2016).Kegiatan usaha gadai syariah juga mengacu pada Fatwa DSN-MUI tentang Rahn,Rahn Tasjily dan Rahn Emas. Pelaksanaan pengawasan dari aspek syariahnya, dilakukan oleh Majelis Ulama Indonesia (MUI) melalui Dewan Pengawas Syariah (DPS) yang ada pada Kantor Cabang Pegadaian Syariah.Pegadaian syariah mempunyai asas, fungsi, dan tujuan yang sejalan dengan asas, fungsi dan tujuan pegadaian konvensional. Akan tetapi, meskipun secara umum terdapat beberapa persamaan, pegadaian syariah memiliki prinsip tersendiri terutama dalam melaksanakan kegiatan usahanya, yang tidak mungkin bisa dikompromikan dengan sistem yang berlaku pada pegadaian konvensional. Secara ringkas, uraian mengenai perbedaan anatara
Pegadaian Syariah dengan pegadaian konvensional, dapat dilihat pada tabel:

Tabel 1 .

Perbedaan Pegadaian Syariah dan Pegadaian Konvensional

\begin{tabular}{|c|c|c|}
\hline No. & $\begin{array}{l}\text { Pegadaian } \\
\text { Syariah }\end{array}$ & $\begin{array}{l}\text { Pegadaian } \\
\text { Konvensional }\end{array}$ \\
\hline 1. & $\begin{array}{l}\text { Kegiatan } \\
\text { usahanya tidak } \\
\text { menerapkan } \\
\text { sistem bunga dan } \\
\text { objeknya halal. }\end{array}$ & $\begin{array}{l}\text { Kegiatan } \\
\text { usahanya } \\
\text { menerapkan } \\
\text { sistem bunga. }\end{array}$ \\
\hline 2. & $\begin{array}{l}\text { Kelebihan lelang } \\
\text { barang jaminan } \\
\text { dikembalikan. }\end{array}$ & $\begin{array}{l}\text { Kelebihan } \\
\text { lelang barang } \\
\text { jaminan tidak } \\
\text { dikembalikan. }\end{array}$ \\
\hline 3. & $\begin{array}{l}\text { Akomodatif atas } \\
\text { keanekaragaman } \\
\text { jenis barang } \\
\text { jaminan }\end{array}$ & $\begin{array}{l}\text { Tidak } \\
\text { akomodatif } \\
\text { atas } \\
\text { keanekara- } \\
\text { gaman jenis } \\
\text { barang } \\
\text { jaminan. }\end{array}$ \\
\hline 4. & $\begin{array}{l}\text { Pengawasan oleh } \\
\text { DPS dan DSN-MUI }\end{array}$ & $\begin{array}{l}\text { Tidak dibawah } \\
\text { pengawasan } \\
\text { DPS dan DSN- } \\
\text { MUI }\end{array}$ \\
\hline 5. & $\begin{array}{l}\text { Penyelesaian } \\
\text { perselisihan } \\
\text { (persengke- taan) } \\
\text { oleh } \quad \text { Basyarnas } \\
\text { dan } \quad \text { Peradilan } \\
\text { Agama }\end{array}$ & $\begin{array}{l}\text { Penyelesaian } \\
\text { perselisihan } \\
\text { oleh Badan } \\
\text { Arbitrase } \\
\text { Nasional } \\
\text { Indonesia } \\
\text { (BANI) dan } \\
\text { Peradilan } \\
\text { Umum } \\
\end{array}$ \\
\hline
\end{tabular}

Sumber: Abdul Ghofur Anshori, 2006, Diolah Peneliti

$$
\text { Menurut Huda dan Heykal }
$$

(2010:280) mekanisme operasional pegadaian syariah dapat digambarkan sebagai berikut; Melalui akad rahn, nasabah menyerahkan barang bergerak dan kemudian pegadaian menyimpan dan merawatnya di tempat yang telah disediakan oleh Kantor Cabang Pegadaian Syariah. Akibat yang timbul dari proses penyimpanan adalah timbulnya biaya-biaya yang meliputi nilai 
Novriansyah, et al/Jurnal Ekonomi Syariah Teori dan Terapan Vol. 6 No. 8 Agustus 2019: 1718-1732; PERAN PEMBIAYAAN PRODUK ARRUM BPKB PT PEGADAIAN SYARIAH DALAM MENGEMBANGKAN USAHA MIKRO KECIL DAN MENENGAH DI KOTA SURABAYA

investasi tempat penyimpanan, biaya perawatan, dan keseluruhan proses kegiatannya. Atas dasar ini dibenarkan pegadaian mengenakan biaya sewa kepada nasabah sesuai jumlah yang disepakati oleh kedua belah pihak. Pegadaian Syariah memperoleh keuntungan dari bea sewa tempat yang dipungut ringkas model mekanisme operasional Pegadaian Syariah, digambarkan sebagai berikut:

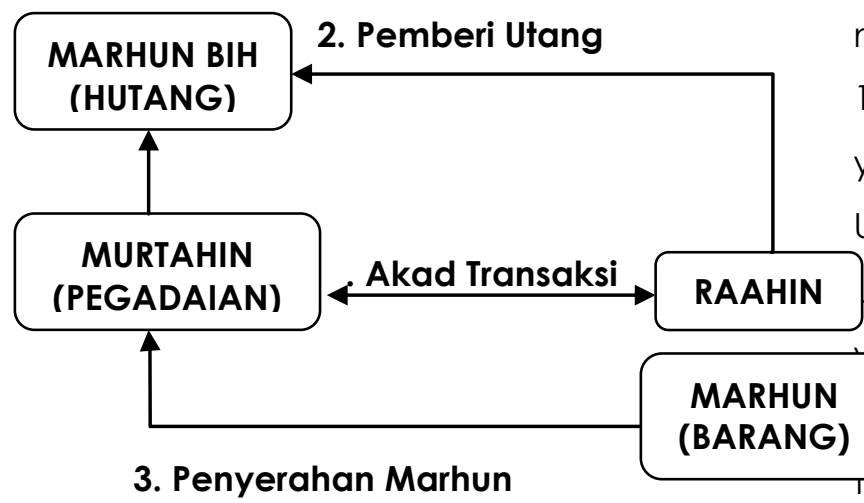

Sumber: Nurul Huda dan Muhammad Heykal, 2010, Diolah Peneliti

Gambar 3.

Mekanisme Operasional Pegadaian Syariah

UMKM adalah unit usaha produktif yang berdiri sendiri, yang dilakukan oleh orang perorangan atau badan usaha disemua sektor ekonomi sehingga mempunyai perang yang sangat penting dan mampu bertahan dalam guncangan ekonomi.Menurut Rudjito (2003) UMKM adalah usaha yang mempunyai peranan penting dalam perekonomian negara Indonesia, baik dari sisi lapangan kerja yang tercipta maupun dari sisi jumlah usahanya khususnya dalam meningkatkan PDB nasional.Berkaitan dengan hal tersebut Islam memandang bahwa salah satu pekerjaan yang mulia adalah melalui jalan perniagaan sehingga bahasan mengenai UMKM adalah kajian kontemporer yang sangat penting, sehingga setiap adanya permasalahan tentang ekonomi, maka peran hukum Islam diperlukan untuk menjawabnya. Hal ini tertera dengan firman Allah SWT dalam kitab suci Al-Qur'an surat An-Nisaa':29.

Perkembangan adalah suatu tindakan, proses, hasil atau pertanyaan menjadi lebih baik (Thoha, 1997:7).Berdasarkan uraian tersebut, maka yang dimaksud dengan pengembangan UMKM adalah suatu tindakan atau proses untuk memajukan kondisi UMKM ke arah ang lebih baik, sehinga UMKM dapat pih baik menyesuaikan dengan eknologi, pasar, dan tantangan yang baru serta perputaran yang cepat dari perubahan yang terjadi.Menurut Resalawati (2011) adapaun sasaran klasifikasi pengembangan UMKM, yaitu:

1. Livelhood Activities, merupakan Usaha Mikro Kecildan Menengah(UMKM) yang digunakan sebagai kesempatan kerja untuk mencari nafkah,yang lebih umum biasa disebut sektor informal, contohnya pedagang kaki lima.

2. Micro Enterprise, merupakan Usaha Mikro Kecil dan Menengah (UMKM) yang memiliki sifat pengrajin tetapi belum memiliki sifat kewirausahaan.

3. Small Dynamic Enterprise, merupakan Usaha Mikro Kecil dan Menengah (UMKM) yang telah memiliki jiwa 
Novriansyah, et al/Jurnal Ekonomi Syariah Teori dan Terapan Vol. 6 No. 8 Agustus 2019: 1718-1732; PERAN PEMBIAYAAN PRODUK ARRUM BPKB PT PEGADAIAN SYARIAH DALAM MENGEMBANGKAN USAHA MIKRO KECIL DAN MENENGAH DI KOTA SURABAYA

kewirausahaan dan mampu menerima pekerjaan subkontrak dan ekspor.

4. Fast Moving Enterprise, merupakan Usaha Mikro Kecil dan Menengah (UMKM) yang telah memiliki jiwa kewirausahaan dan akan melakukan transformasi menjadi usaha besar (UB).

Dalam konteks pengembangan UMKM di Kota Surabaya terdapat prinsip Pengembangan sebagai indikator yang digunakan dalam mengukur keberhasilan peran Produk ARRUM BPKB dalam mengembangkan UMKM di kota Surabaya yang tertuang pada UU No. 20 Tahun 2008 Tentang Usaha Mikro,Kecil dan Menengah, meliputi:

1. Standar Fasilitas

2. Standar Bimbingan

3. Standar Pembiayaan

\section{METODE PENELITIAN}

Pendekatan yang akan digunakan dalam penelitian ini adalah pendekatan penelitian kualitatif. Menurut Yin (2009:2) pendekatan kualitatif adalah pendekatan dengan menggunakan data yang berupa kalimat tertulis atau lisan, persitiwaperistiwa, pengetahuan atau proyek studi yang bersifat deskriptif. Strategi yang digunakan dalam penelitian ini adalah strategi penelitian studi kasus.

Ruang lingkup penelitian terbatas pada peran pembiayaan produk ARRUM,BPKB serta bagaimana dampak penyaluran pembiayaan produk ARRUM BPKB yang dilakukan oleh Pegadaian Syariah Kantor Unit Kutai Surabaya dalam mengembangkan UMKM di Kota
Surabaya. Objek dalam penelitian ini adalah Kantor Unit PT. Pegadaian Syariah Kutai Surabaya khususnya produk ARRUM BPKB dan subjek dalam penelitian ini adalah pegawai Kantor Unit PT. Pegadaian Syariah Kutai Surabaya dan kelompok UMKM yang mendapatkan pembiayaan produk ARRUM BPKB.

Dalam penelitian kualitatif data dibagi menjadi dua, yaitu data primer dan data sekunder. Data primer adalah data yang didapat dan dikumpulkan dari sumber pertama atau diperoleh secara langsung dari sumber asli. Sedangkan data sekunder adalah data yang telah dikumpulkan oleh pihak lain dan merupakan data tidak langsung yang diberikan kepada pengumpul data.Dalam menentukan unit analisis, peneliti menggunakan teknik purposive untuk menentukan informan bagi penelitian.Alasan menggunakan teknik tersebut, yakni dalam pengambilan informasi peneliti memilih orang atau individu yang dianggap paling mengetahui tentang apa yang diharapkan mengenai topik yang diteliti.

$$
\text { Menurut Yin }
$$

(2009:103)

menjelaskan bahwa ada enam sumber bukti yang dijadikan fokus bagi pengumpul data studi kasus, yaitu: dokumen, rekaman, wawancara, arsip, observasi langsung, observasi pemeran, dan perangkat fisik.Penelitian ini menggunakan teknik triangulasi sumber yang dilakukan dengan cara mengkroscek data yang telah didapat 
Novriansyah, et al/Jurnal Ekonomi Syariah Teori dan Terapan Vol. 6 No. 8 Agustus 2019: 1718-1732; PERAN PEMBIAYAAN PRODUK ARRUM BPKB PT PEGADAIAN SYARIAH DALAM MENGEMBANGKAN USAHA MIKRO KECIL DAN MENENGAH DI KOTA SURABAYA

melalui berbagai sumber.Dalam penelitian ini teknik triangulasi data sumber dilakukan untuk menguji validitas data tentang peran pembiayaan produk ARRUM BPKB. Maka pengumpulan dan pengujian data yang telah diperoleh dapat dilakukan kepada nasabah yang menjadi peserta produk ARRUM BPKB dalam bentuk pembiayaan, selain itu dapat pula dilakukan dengan membandingkan hasil wawancara dengan dokumen yang berkaitan.

\section{HASIL DAN PEMBAHASAN}

Berdasarkan Undang-Undang Republik Indonesia Nomor 20 Tahun 2008 Tentang Usaha Mikro, Kecil dan Menengah standar fasilitas adalah upaya yang dilakukan Pemerintah, Pemerintah Daerah secara sinergis dalam bentuk memfasilitasi pengembangan usaha dalam bidang produksi dan pengolahan, pemasaran, sumber daya manusia dan desain dan teknologi terhadap Usaha Mikro, Kecil, dan Menengah sehingga mampu tumbuh dan berkembang menjadi usaha yang tangguh dan mandiri. Output yang dihasilkan dalam standar fasilitas berkaitan dengan peningkatan sarana dan prasarana guna mendukung usaha nasabah setelah menerima pembiayaan produk ARRUM BPKB.

Penelitian ini dilakukan kepada dua orang nasabah yang merupakan penerima pembiayaan produk ARRUM BPKB PT. Pegadaian Syariah kantor unit Kutai Surabaya yang dipilih secara acak untuk mengetahui pengembangan UMKM dari aspek-aspek fasilitas dan aset terkait usaha nasabah, pada saat sebelum mendapatkan pembiayaan produk ARRUM BPKB dan sesudah mendapatkan pembiayaan produk ARRUM BPKB. Dibawah ini merupakan tabel data hasil wawancara dengan informan terkait.

Tabel 2.

Standar Fasilitas

\begin{tabular}{|c|c|c|c|}
\hline No & $\begin{array}{c}\text { Informa } \\
n\end{array}$ & $\begin{array}{c}\text { Sebelum } \\
\text { Mendapat } \\
\text { Pembiayaa } \\
n\end{array}$ & $\begin{array}{c}\text { Setelah } \\
\text { Mendapat } \\
\text { Pembiayaa } \\
\mathbf{n}\end{array}$ \\
\hline 1. & $\begin{array}{l}\text { Informa } \\
\text { n ketiga }\end{array}$ & $\begin{array}{l}\text { 1. Luas } \\
\text { usaha } 2 \times 4 \\
\text { meter. } \\
\text { 2. Memiliki } \\
\text { satu } \\
\text { kompor } \\
\text { 3. Memiliki } \\
\text { satu } \\
\text { tabung } \\
\text { LPG } \\
\text { 4. Memiliki } \\
\text { satu Panci } \\
5 \text {. Memiliki } \\
\text { dua meja } \\
\text { ukuran } \\
\text { 2x0,5 meter } \\
\text { dan empat } \\
\text { kursi ukuran } \\
2 \times 0,5 \\
\text { meter. } \\
6 . \\
\text { Kapasitas } \\
\text { produksi } \\
80-90 \\
\text { mangkok } \\
\text { per hari }\end{array}$ & $\begin{array}{l}\text { 1. Luas } \\
\text { usaha 4x6 } \\
\text { meter. } \\
\text { 2. Memiliki } \\
\text { dua } \\
\text { kompor. } \\
\text { 3. Memiliki } \\
\text { dua } \\
\text { tabung } \\
\text { LPG. } \\
4 . \quad \text { Memiliki } \\
\text { dua panci. } \\
5 . \quad \text { Memiliki } \\
\text { tiga meja } \\
\text { Ukuran } \\
2 \times 0,5 \text { meter } \\
\text { dan enam } \\
\text { kursi ukuran } \\
2 \times 0,5 \\
\text { meter. } \\
6 . \\
\text { Kapasitas } \\
\text { produksi } \\
150-160 \\
\text { mangkok } \\
\text { per hari. }\end{array}$ \\
\hline 2. & $\begin{array}{l}\text { Informa } \\
\mathrm{n} \\
\text { keemp } \\
\text { at }\end{array}$ & $\begin{array}{l}\text { 1. Luas } \\
\text { garasi } \\
10 \times 20 \\
\text { Meter. } \\
\text { 2. Memiliki } \\
\text { satu truck } \\
\text { tronton. }\end{array}$ & $\begin{array}{l}\text { 1. Luas } \\
\text { garasi } \\
20 \times 20 \\
\text { meter. } \\
\text { 2. Memiliki } \\
\text { dua truck } \\
\text { tronton. }\end{array}$ \\
\hline
\end{tabular}

Sumber: Hasil Wawancara Dengan Nasabah Tanggal 13, 18 dan 23 Mei 2019, Diolah Peneliti 
Novriansyah, et al/Jurnal Ekonomi Syariah Teori dan Terapan Vol. 6 No. 8 Agustus 2019: 1718-1732; PERAN PEMBIAYAAN PRODUK ARRUM BPKB PT PEGADAIAN SYARIAH DALAM MENGEMBANGKAN USAHA MIKRO KECIL DAN MENENGAH DI KOTA SURABAYA

Berdasarkan Undang-Undang

Republik Indonesia Nomor 20 Tahun 2008

Tentang Usaha Mikro, Kecil dan Menengah standar bimbingan adalah upaya yang dilakukan Pemerintah, Pemerintah Daerah secara terstruktur dan sistematis dalam bentuk melakukan pembinaan dengan cara meningkatkan kemampuan manajemen, memberikan dukungan jarinngan pemasaran, meningkatkan kemampuan informasi dan teknologi serta menyediakan tenaga konsultan professional dalam bidang usaha terhadap Usaha Mikro, Kecil, dan Menengah melalui pelatihan, pendidikan dan motivasi sehingga mampu tumbuh dan berkembang menjadi usaha yang tangguh, mandiri dan meningkatkan perekonomian masyarakat. Output yang dihasilkan dalam standar bimbingan berkaitan dengan kemampuan dalam berwirausaha oleh nasabah, guna mendukung kelancaran dan keberlanjutan usaha setelah menerima pembiayaan produk ARRUM BPKB.

Penelitian ini dilakukan kepada dua orang nasabah yang merupakan penerima pembiayaan produk ARRUM BPKB PT. Pegadaian Syariah kantor unit Kutai Surabaya yang dipilih secara acak untuk mengetahui pengembangan UMKM dari aspek kemampuan atau wawasan yang dimiliki nasabah, pada saat sebelum mendapatkan pembiayaan produk ARRUM BPKB dan sesudah mendapatkan pembiayaan produk ARRUM BPKB. Dibawah ini merupakan tabel data hasil wawancara dengan informan terkait.

Tabel 3.

Standar Bimbingan

\begin{tabular}{|c|c|c|c|}
\hline Indikator & Peningkatan & Informan Ketiga & Informan Keempat \\
\hline \multirow{2}{*}{$\begin{array}{l}\text { 1. Pembinaan } \\
\text { dalam bentuk } \\
\text { diskusi } \\
\text { kelompok dan } \\
\text { sharing individu }\end{array}$} & Sebelum & $\begin{array}{l}\text { Tidak pernah menerima } \\
\text { pembinaan dalam } \\
\text { bentuk diskusi kelompok } \\
\text { dan sharing individu }\end{array}$ & $\begin{array}{l}\text { Tidak pernah menerima } \\
\text { pembinaan dalam bentuk } \\
\text { diskusi kelompok dan sharing } \\
\text { individu }\end{array}$ \\
\hline & Sesudah & $\begin{array}{l}\text { Menerima pembinaan } \\
\text { dalam bentuk diskusi } \\
\text { kelompok dan sharing } \\
\text { individu sehingga } \\
\text { mengetahui kiat-kiat } \\
\text { dalam berwirausaha } \\
\text { agar dapat } \\
\text { berkembang. }\end{array}$ & $\begin{array}{l}\text { Menerima pembinaan dalam } \\
\text { bentuk diskusi kelompok dan } \\
\text { sharing individu serta mampu } \\
\text { menangani masalah dalam } \\
\text { usaha dan mengetahui kiat-kiat } \\
\text { dalam berwirausaha. }\end{array}$ \\
\hline \multirow[t]{2}{*}{$\begin{array}{l}\text { 2. Kemampuan } \\
\text { Manajemen }\end{array}$} & Sebelum & $\begin{array}{l}\text { Tidak mengetahui } \\
\text { manajemen keuangan } \\
\text { khususnya } \\
\text { mengalokasikan dana } \\
\text { setelah mendapat } \\
\text { pembiayaan }\end{array}$ & $\begin{array}{l}\text { Tidak mengetahui manajemen } \\
\text { usaha khususnya dalam } \\
\text { melakukan pengembangan } \\
\text { aset. }\end{array}$ \\
\hline & Sesudah & $\begin{array}{l}\text { Mampu mengalokasikan } \\
\text { dana dengan cara } \\
\text { melakukan perluasan } \\
\text { tempat usaha, } \\
\text { meningkatkan alat }\end{array}$ & $\begin{array}{l}\text { Mampu melakukan } \\
\text { pengembangan aset dengan } \\
\text { penambahan satu unit truck } \\
\text { tronton sehingga menjadi dua } \\
\text { unit. }\end{array}$ \\
\hline
\end{tabular}


Novriansyah, et al/Jurnal Ekonomi Syariah Teori dan Terapan Vol. 6 No. 8 Agustus 2019: 1718-1732; PERAN PEMBIAYAAN PRODUK ARRUM BPKB PT PEGADAIAN SYARIAH DALAM MENGEMBANGKAN USAHA MIKRO KECIL DAN MENENGAH DI KOTA SURABAYA

\begin{tabular}{|c|c|c|c|}
\hline & & produksi dan aset. & \\
\hline \multirow[t]{2}{*}{$\begin{array}{l}\text { 3. Kemampuan } \\
\text { Akuntansi }\end{array}$} & Sebelum & $\begin{array}{l}\text { Tidak mengetahui cara } \\
\text { melakukan pembukuan } \\
\text { dan tidak mempunyai } \\
\text { pembukuan dalam } \\
\text { setiap transaksi bisnis. }\end{array}$ & $\begin{array}{l}\text { Tidak melakukan pembukuan } \\
\text { dalam setiap transaksi usaha } \\
\text { khususnya biaya tak terduga, } \\
\text { omzet dan laba bersih usaha }\end{array}$ \\
\hline & Sesudah & $\begin{array}{l}\text { Mengetahui cara } \\
\text { melakukan pembukuan } \\
\text { dan melakukan } \\
\text { pencatatan setiap } \\
\text { transaksi bisnis khususnya } \\
\text { dalam pembelian } \\
\text { bahan baku, beban } \\
\text { usaha, persediaan, } \\
\text { penjualan tau omzet } \\
\text { dan laba bersih usaha. }\end{array}$ & $\begin{array}{l}\text { Melakukan pembukuan dalam } \\
\text { transaksi bisnis khususnya } \\
\text { omzet, laba bersih dan biaya- } \\
\text { biaya lainnya. }\end{array}$ \\
\hline \multirow[t]{2}{*}{$\begin{array}{l}\text { 4. Kemampuan } \\
\text { Pemasaran }\end{array}$} & Sebelum & $\begin{array}{l}\text { Tidak mengetahui cara } \\
\text { memasarkan produk }\end{array}$ & $\begin{array}{l}\text { Melakukan pemasaran } \\
\text { dengan memasang papan } \\
\text { persewaan truck tronton }\end{array}$ \\
\hline & Sesudah & $\begin{array}{l}\text { Mengetahui cara } \\
\text { memasarkan produknya } \\
\text { dengan cara berjualan } \\
\text { di pinggir jalan yang } \\
\text { terdapat banner besar. } \\
\text { dan memasarkan } \\
\text { produknya dengan cara } \\
\text { mulut ke mulut serta di } \\
\text { media social (facebook, } \\
\text { instagram). }\end{array}$ & $\begin{array}{l}\text { Melakukan pemasaran melalui } \\
\text { pemasangan persewaan truck } \\
\text { tronton di lokasi usaha, promosi } \\
\text { melalui media social (olx, } \\
\text { facebook) dan mendatangi } \\
\text { berbagai perusahaan dengan } \\
\text { menawarkan truck trontonnya } \\
\text { tersebut. }\end{array}$ \\
\hline
\end{tabular}

Sumber: Hasil Wawancara Dengan Nasabah Tanggal 13, 18 dan 23 Mei 2019, Diolah Peneliti

Berdasarkan Undang-Undang

Republik Indonesia Nomor 20 Tahun 2008

Tentang Usaha Mikro, Kecil dan Menengah standar pembiayaan adalah penyediaan dana oleh pemerintah, pemerintah daerah, dunia dsaha, dan masyarakat melalui bank, koperasi, dan lembaga keuangan bukan bank, untuk mengembangkan dan memperkuat permodalan Usaha Mikro, Kecil, dan Menengah. Output yang dihasilkan dalam standar pembiayaan berkaitan dengan omzet usaha nasabah, guna mendukung kelancaran dan keberlanjutan usaha setelah menerima pembiayaan produk ARRUM BPKB.
Penelitian ini dilakukan kepada dua orang nasabah yang merupakan penerima pembiayaan produk ARRUM BPKB PT. Pegadaian Syariah kantor unit Kutai Surabaya yang dipilih secara acak untuk mengetahui pengembangan UMKM dari aspek omzet bisnis yang dimiliki nasabah, pada saat sebelum mendapatkan pembiayaan produk ARRUM BPKB dan sesudah mendapatkan pembiayaan produk ARRUM BPKB. Dibawah ini merupakan tabel data hasil wawancara dengan informan terkait.

Tabel 4.

Standar Pembiayaan

\begin{tabular}{|c|c|c|c|}
\hline No & $\begin{array}{c}\text { Informa } \\
\cdot\end{array}$ & $\begin{array}{c}\text { Sebelum } \\
\text { Mendapat } \\
\text { Pembiayaa }\end{array}$ & $\begin{array}{c}\text { Setelah } \\
\text { Mendapat } \\
\text { Pembiayaa }\end{array}$ \\
\hline
\end{tabular}


Novriansyah, et al/Jurnal Ekonomi Syariah Teori dan Terapan Vol. 6 No. 8 Agustus 2019: 1718-1732; PERAN PEMBIAYAAN PRODUK ARRUM BPKB PT PEGADAIAN SYARIAH DALAM MENGEMBANGKAN USAHA MIKRO KECIL DAN MENENGAH DI KOTA SURABAYA

\begin{tabular}{|c|l|l|l|}
\hline & & \multicolumn{1}{|c|}{$\mathbf{n}$} & \multicolumn{1}{|c|}{$\mathbf{n}$} \\
\hline 1. & $\begin{array}{l}\text { Informa } \\
\text { n ketiga }\end{array}$ & $\begin{array}{l}\text { Omzet } \\
\text { bisnis Rp. } \\
700.000 \\
\text { perhari }\end{array}$ & $\begin{array}{l}\text { Omzet } \\
\text { bisnis Rp. } \\
1.200 .000 \\
\text { perhari }\end{array}$ \\
\hline 2. & $\begin{array}{l}\text { Informa } \\
\text { n } \\
\text { keemp } \\
\text { at }\end{array}$ & $\begin{array}{l}\text { Omzet } \\
\text { bisnis Rp. } \\
5.000 .000 \\
\text { perbulan }\end{array}$ & $\begin{array}{l}\text { Omzet } \\
\text { bisnis Rp. Rerbulan } \\
10.000 .000 \\
\text { perbula }\end{array}$ \\
\hline
\end{tabular}

Sumber: Hasil Wawancara Dengan Nasabah Tanggal 13, 18 dan 23 Mei 2019, Diolah Peneliti

\section{DAFTAR PUSTAKA}

Al-Zuhayli, Wahbah.1985. al-Figh al Islam wa' Adilatuh. Damaskus: Dar al-Fikr

Anshori, Abdul Ghofur. 2006. Gadai Syariah di Indonesia, Konsep, Implementasidan Institusionalisasi. Yogyakarta: UGM Press.

Badan Pusat Statistik, 2017. Laju Pertumbuhan Produk Regional Domestik Bruto Kota Surabaya.Di https://surabayakota.bps.go.id. Di Akses (3Maret 2018)

Diana, Nana. 2016. Pengaruh Pembiayaan Gadai Emas Dan Pembiayaan Arrum Terhadap Perolehan Laba Pegadaian Syariah. Jurnal Ar-Rahn. 1 (2).

Fatwa Dewan Syariah Nasional-Majelis Ulama Indonesia Nomor 25/DSNMUI/III/2002 tentang Rahn

Fatwa Dewan Syariah Nasional-Majelis Ulama Indonesia Nomor 26/DSNMUI/III/2002 tentang Rahn Emas,

Fatwa Dewan Syariah Nasional-Majelis Ulama Indonesia Nomor 68/DSNMUI/III/2008 tentang Rahn Tasjily
Fatwa Dewan Syariah Nasional-Majelis Ulama Indonesia Nomor 92/DSN$\mathrm{MUI} / \mathrm{IV} / 2014$ tentang Pembiayaan Yang Disertai Rahn

Herianingrum, Sri. 2013. Pengaruh Pembiayaan Bank Syariah Terhadap Kinerja Usaha dan Kesejahteraan Pengusaha Kecil Tijarah Zira'ah di Jawa Timur.Disertasi tidak diterbitkan. Surabaya: Fakultas Ekonomi dan Bisnis Universitas Airlangga.

https://pegadaiansyariah.co.id/arrumbpkb

Huda, Nurul dan Mohamad Heykal. 2010. Lembaga Kevangan Islam:Tinjauan Teoritis dan Praktis. Jakarta:Kencana

Kara, Muslimin. 2013. Kontribusi Pembiayaan Perbankan Syariah terhadap Pengembangan Usaha Mikro, Kecil dan Menengah.Ahkam.Vol. 13, No. 2, hal. 315-322.

M.A., Mannan. 1975. Islamic Economics; Theory and Practice. Lahore: Houder and Stoughton Ltd.

Masyrafina, I. 2017. Kontribusi UMKM untuk Pertumbuhan Ekonomi Diprediksi Turun.Republika.co.id, edisi Jumat tanggal $19 \quad$ Agustus2017. http://republika.co.id/berita/ekono mi/makro/17/08/18/ouvlqv382kontribusiumkmuntukpertumbuhan-ekonomi-diprediksiturun. Diakses 04 Maret 2019. 
Novriansyah, et al/Jurnal Ekonomi Syariah Teori dan Terapan Vol. 6 No. 8 Agustus 2019: 1718-1732; PERAN PEMBIAYAAN PRODUK ARRUM BPKB PT PEGADAIAN SYARIAH DALAM MENGEMBANGKAN USAHA MIKRO KECIL DAN MENENGAH DI KOTA SURABAYA

Mulazid, Ade Sofyan. 2016. Kedudukan Sistem Pegadaian Syariah. Jakarta: PT Kharisma Putra Utama

Mutmainnah. 2012. Analisis Pembiayaan Arrum PT. Pegadaian Syariah terhadap Pengembangan Usaha Mikro Kecil (Studi Kasus pada Kantor Cabang PT. Pegadaian Syariah Sentral Makassar).Skripsi. Makassar: Fakultas Syariah dan Hukum Universitas Islam Negeri (UIN) Alauddin.

Perum Pegadaian, Laporan Tahunan 2015 (Jakarta: Perum Pegadaian, 2016).

Perum Pegadaian, Laporan Tahunan 2016 (Jakarta: Perum Pegadaian, 2017). Perum Pegadaian, Laporan Tahunan 2017 (Jakarta: Perum Pegadaian, 2018). Perum Pegadaian, Laporan Tahunan 2018 (Jakarta: Perum Pegadaian, 2019). Prasetya, R.AY dan S. Herianingrum. 2016. Peranan Baitul Maal Wa Tamwil Meningkatkan Usaha Mikro Melalui Pembiayaan Mudharabah. Jurnal Syarikah. Vol. 2, No. 2

Resalawati, Ade. 2011. Pengaruh perkembangan usaha kecil menengah terhadap pertumbuhan ekonomi pada sektor UKM Indonesia. Skripsi.Jakarta Fakultas Ekonomi dan Bisnis Universitas Islam Negeri Syarif Hidayatullah.

Rivai, Veithzal dan Andria Permata Veithzal. 2008. Is/amic Financial Management. Jakarta: PT RajaGrafindo Persada.

Rudjito.2003. Peranan Lembaga Kevangan Mikro dalam Otonomi Daerah guna Menggerakkan Ekonomi Rakyat dan Menanggulangi

Kemiskinan.www.ekonomirakyat.or g. Di Akses (3 Maret 2018).

Syafruddin. 2014. Pengaruh Pemberian Kredit Kreasi PT. Pegadaian (Persero) Cabang Sumbawa Besar terhadap Modal Kerja Usaha Mikro dan Kecil di Kabupaten Sumbawa Tahun 2012. Jurnal Ekonomi dan Bisnis.Vol. 1, No.5, hal.13-23.

Thoha, Miftah. 1997. Pembinaan Organisasi (Proses Diagnosa dan Intervensi). Jakarta: PT. Raja Grafindo Persada

Undang-Undang Republik Indonesia Nomor 20 Tahun 2008 Tentang Usaha Mikro, Kecil dan Menengah. www.pegadaian.co.id.

Yin, Robert. K. 2009. Studi Kasus; Desain dan Metode. Jakarta. Raja Grafindo Persada. 